\title{
EXTRACTION BY ELECTROFLOTATION OF IRON, CHROMIUM AND ALUMINIUM HYDROXIDES FROM AQUEOUS SOLUTIONS OF SODIUM CHLORIDES AND SULPHATES IN THE PRESENCE OF $\mathrm{Mg}^{2+}, \mathrm{Ca}^{2+}$ AND SURFACTANTS OF DIFFERENT TYPES
}

\author{
A. V. Kolesnikov' ${ }^{1}$, Than So Htay', V. A. Kolesnikov¹, V. S. Kovalenko² \\ ${ }^{1}$ D. Mendeleev University of Chemical Technology of Russia (Moscow, Russia) \\ 2 National University of Science and Technology MISiS (Moscow, Russia)
}

\author{
E-mail: artkoles@list.ru
}

\section{AUTHOR'S INFO}

\begin{abstract}
A. V. Kolesnikov, Associate Prof., Dept. "Innovative materials and corrosion protection",

Than So Htay, Post-graduate Student, Dept. "Technology of inorganic substances and electrochemical processes";

V. A. Kolesnikov, Dr. Eng., Prof., Head of Dept. "Innovative materials and corrosion protection";

V. S. Kovalenko, Dr. Eng., Prof., Head of Dept. "Open cast mining"
\end{abstract}

Key words:

electroflotation, hydroxides, $\mathrm{Fe}, \mathrm{Cr}$, surfactants, electrolytes, sodium chloride, sodium sulphate, reagents, magnesium hydroxide, calcium hydroxide, electroflotation kinetics.

\section{A B S T RAC T}

This paper examines an electroflotation process in which iron hydroxides are recovered from chloride-sulphate solutions in the presence of surfactants of different types, as well as calcium and magnesium cations used as reagents. It was found that calcium and magnesium cations lower the recovery of iron hydroxides by 30 to $40 \%$. Introduction of surfactants intensifies the recovery of iron (III) hydroxides making it reach 89 to $98 \%$. It was found that the anionic surfactant NaDDS produces a positive effect on the recovery of chromium (III) hydroxides by electroflotation by raising the recovery rate by 30 to $40 \%$ and expanding the effective pH range to 9 . NaDDS improves the recovery of the mixture of iron, chromium and aluminium hydroxides in electrolytic solutions $(10 \mathrm{~g} / 1)$. Water treatment procedures are described aimed at removing iron (II, III) ions and the iron/chromium mixture.

\section{Introduction}

The wastewater generated as a result of steel surface treatment processes contains $\mathrm{Fe}^{2+}, \mathrm{Fe}^{3+}, \mathrm{Cr}^{3+}, \mathrm{Cr}^{6+}$, $\mathrm{Ni}^{2+}, \mathrm{Co}^{2+}$, as well as ions of some other metals [1,2]. It is usually due to the use of $\mathrm{HCl}, \mathrm{H}_{2} \mathrm{SO}_{4}, \mathrm{H}_{3} \mathrm{PO}_{4}$ that base electrolytes form in wastewater. Neutralization of the former results in the formation of $\mathrm{NaCl}, \mathrm{Na}_{2} \mathrm{SO}_{4}(1-5 \mathrm{~g} / \mathrm{l})$, soluble salts of $\mathrm{Mg}^{2+}, \mathrm{Ca}^{2+}(0.1-0.5 \mathrm{~g} / \mathrm{l})$, chlorides and carbonates [3, 4]. Wastewater generated by mining and metallurgical complexes has a more complex composition. Thus, it may contain oxides of $\mathrm{Fe}, \mathrm{Ca}, \mathrm{Mg}, \mathrm{Si}$, sulphides of $\mathrm{Zn}, \mathrm{Pb}, \mathrm{Cu}, \mathrm{Mn}$, hydroxides of Ti, Al, Fe [5, 6]. Even though wastewater contains ions of numerous different heavy and non-ferrous metals, it also contains 20 to $30 \%$ of iron (II, III) oxides and hydroxides. Some researchers [7] are working on developing basic techniques to help reduce the environmental impact of the ferrous metals industry. They are also working on developing the concept of waste-free metals production [8]. The majority of professionals in the field resort to modern technology to neutralize liquid, solid and gaseous wastes.

Reagents made with $\mathrm{Fe}(\mathrm{III}), \mathrm{FeCl}_{3}, \mathrm{Fe}_{2}\left(\mathrm{SO}_{4}\right)_{3}$ are used as coagulants in wastewater treatment processes that help remove suspended particles, emulsions and surfac- tants $[9,10] . \mathrm{Fe}(\mathrm{III})$ ions often enter the wastewater in great quantities due to the use of electrocoagulation and galvanocoagulation. In these processes, iron-containing wastes (shavings, scrap, oxides) are used as anodes [6, 9-12]. A study is carried out that looks at the steel industry wastes utilized as sorbents (iron oxides, hydroxides) in industrial water circuits [13].

All the above suggests that techniques are required that would help extract the disperse phase of $\mathrm{Fe}(\mathrm{OH})_{3}$ from wastewater ponds. There are certain techniques for extracting the disperse phase of $\mathrm{Fe}(\mathrm{OH})_{3}$ from aqueous solutions with complex compositions. They include electrochemical, membrane and flotation techniques.

The advantages and drawbacks of the above mentioned techniques are considered in detail in the following reviews and monographs: [14-17].

Analysis shows that the flotation process delivers certain advantages when it is used to remove suspended particles from wastewater in the presence of organic components, surfactants (SAA), lubricoolants and solvents.

This paper describes the findings of some recent studies that looked at the use of electroflotation to recover iron, chromium and aluminium hydroxides from aqueous electrolytic solutions, as well as at some wastewater treatment processes. 
The paper examines the process of recovering iron hydroxides $\left(\mathrm{Fe}(\mathrm{OH})_{3}, \mathrm{Al}(\mathrm{OH})_{3}, \mathrm{Cr}(\mathrm{OH})_{3}\right)$ in the $\mathrm{NaCl}$ and $\mathrm{Na}_{2} \mathrm{SO}_{4}$ electrolytes in the presence of surfactants and the $\mathrm{Ca}^{2+}, \mathrm{Mg}^{2+}$ cations by electroflotation.

The above systems are often used for wastewater treatment by chemical, mining and metallurgical industries. Thus, for instance, when big pipes are treated in acid solutions $\left(\mathrm{HCl}, \mathrm{H}_{2} \mathrm{SO}_{4}\right)$ before protective coatings are installed on them, the $\mathrm{Fe}^{2+}$ and $\mathrm{Fe}^{3+}$ ions, sulphuric and hydrochloric acids, as well as iron oxides and other contaminants enter the wastewater as a result. The amount of generated wastewater can reach dozens of cubic metres an hour, as in the case of Novolipetsk Iron \& Steel Works.

\section{Research methods}

Both laboratory and pilot units were used to study the electroflotation process.

The process efficiency was analyzed based on the recovery rate $\alpha(\%)$, which is calculated with the help of the following formula (1):

$$
\alpha=\left(C_{\text {initial }}-C_{\text {final }}\right) / C_{\text {initial }} \cdot 100 \%,
$$

The concentration of iron, chromium and aluminium was determined by means of atomic adsorption analysis on the KVANT-AFA unit (Russia) available at the Mendeleev University's Shared Knowledge Centre. Detailed descriptions of the techniques are given in the papers listed in the references.

\section{Experimental results}

A great number of papers and reviews [18-20] have been published that looked at the modelling of electroflotation processes, process kinetics and extraction of the disperse phase with the help of electrochemically generated $\mathrm{H}_{2}, \mathrm{O}_{2}$ bubbles. However, because of changing particle size, bubbles in time, trapping efficiency and a number of other parameters, it can be difficult to calculate certain parameters.

Analysis of the reviews shows that a great number of factors influence the disperse phase (MeX) trapping efficiency and the likelihood of a particle/bubble $\left(\mathrm{H}_{2}, \mathrm{O}_{2}\right)$ complex being formed. Such factors include $\mathrm{pH}$ of the medium, the type of electrolyte, salt composition, cations, anions, flocculants and surfactants. [21-24]

The key steps towards an enhanced electroflotation process performance include the following: gas saturation control to ensure an efficient $\mathrm{H}_{2}-, \mathrm{O}_{2}$-to-particle contact; an increased particle size (flocculants, $\mathrm{pH}$, coagulants); a changed $\zeta$-potential ( $\mathrm{pH}$, surfactants, cations, anions); surface hydrophobization (anionic, cationic, nonionic surfactants).

Let's consider the results of experiments that looked at the extraction by electroflotation of iron and chromium hydroxides in the presence of alkali metal cations, which can often be found in wastewater generated by steel processing facilities or are used as precipitation reagents for metals and as neutralization reagents for sulphuric and hydrochloric acids [23, 24].

The study that looked at how the concentration of magnesium ions influences the extraction by electroflotation of iron hydroxides in sodium chloride solutions shows that the recovery rate tends to decrease as the concentration of $\mathrm{Mg}^{2+}$ rises from 0.1 to $1 \mathrm{~g} / \mathrm{l}$.

Analysis shows that $\mathrm{Mg}^{2+}$ ions inhibit the extraction of $\mathrm{Fe}(\mathrm{OH})_{3}$ by electroflotation bringing the recovery rate down from 94 to $50 \%$. This effect is associated with the adsorption of $\mathrm{Mg}^{2+}$ ions on $\mathrm{Fe}(\mathrm{OH})_{3}$ which leads to a rise in the positive value of the $\zeta$-potential to $+20 \ldots+25 \mathrm{mV}$. $\mathrm{Fe}(\mathrm{OH})_{3}$ has a negative potential, which is equal to $-2 \mathrm{mV}$ in $\mathrm{NaCl}$ solution at $\mathrm{pH}=7 \pm 0.5$, and to $-8 \mathrm{mV}$ in sodium sulphate solutions. The iron hydroxide particle size at $\mathrm{pH}$ $7-8$ is $45-50 \mu \mathrm{m}$.

A similar inhibiting effect was observed in the case of calcium and barium ions.

The electroflotation efficiency sees a dramatic decrease within the range of concentrations up to $500 \mathrm{mg} / \mathrm{l}$, in which the adsorption of $\mathrm{Mg}^{2+}, \mathrm{Ca}^{2+}, \mathrm{Ba}^{2+}$ ions on $\mathrm{Fe}(\mathrm{OH})_{3}$ is maximum. At higher concentrations ( $>500 \mathrm{mg} / \mathrm{l})$, the adsorption of $\mathrm{Mg}^{2+}, \mathrm{Ca}^{2+}, \mathrm{Ba}^{2+}$ remains almost unchanged as it is already at its highest.

Introduction of surfactants (anionic surfactants in the first place) leads to a higher $\mathrm{Fe}(\mathrm{OH})_{3}$ recovery rate due to surfactant adsorption through substitution of water molecules and surface hydrophobization. Thus, when the concentration of metals is $0.5 \mathrm{~g} / \mathrm{l}$, the recovery rate rises to $98 \%$ in the presence of $\mathrm{Ba}^{2+}$, to $89 \%$ in the presence of $\mathrm{Ca}^{2+}$ and to $67 \%$ in the presence of $\mathrm{Mg}^{2+}$.

The results of experiments that looked at the adsorption of surfactants on iron and aluminium hydroxides are described in the following papers $[25,26]$.

Table 1 shows how surfactants of different types influence the extraction by electroflotation of $\mathrm{Fe}(\mathrm{OH})_{3}$ in the presence of $\mathrm{Mg}^{2+}, \mathrm{Ca}^{2+}$.

The main positive effect produced by surfactants includes surface hydrophobization. This is especially true for anionic and nonanionic surfactants as they help remove $\mathrm{H}_{2} \mathrm{O}$ molecules from the $\mathrm{Fe}(\mathrm{OH})_{3}$ surface.

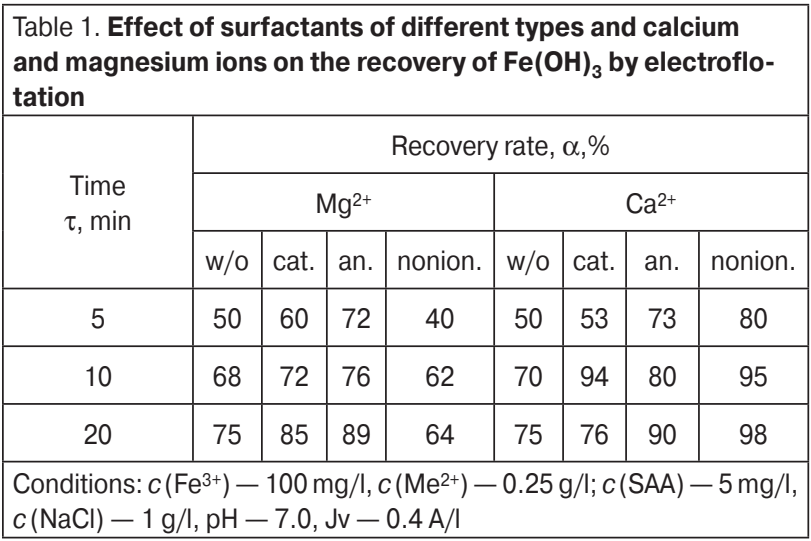




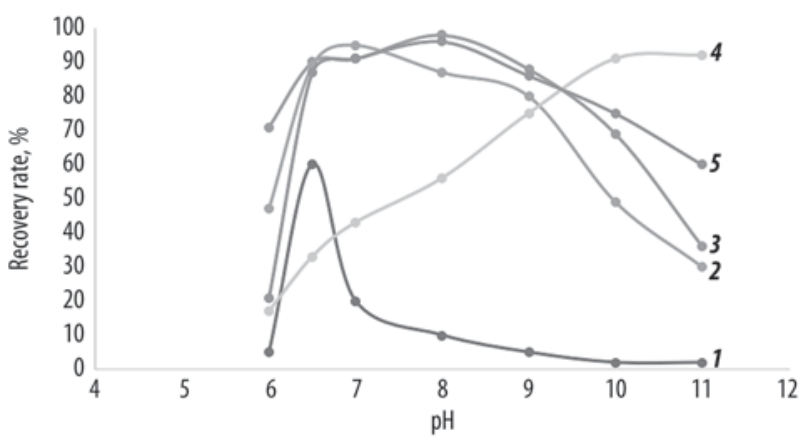

Fig. 1. Effect of $\mathrm{pH}$ and surfactants of different types on the $\mathrm{Cr}(\mathrm{OH})_{3}$ recovery rate (Conditions: $c\left(\mathrm{Cr}^{3+}\right)-$ $50 \mathrm{mg} / \mathrm{l} ; c\left(\mathrm{Na}_{2} \mathrm{SO}_{4}\right)-\mathbf{~ g} / \mathbf{l} ; c(\mathrm{SAA})-5 \mathrm{mg} / \mathrm{l}$; $\left.J_{v}-0.4 \mathrm{~A} / \mathrm{l} ; \tau-20 \mathrm{~min}\right)$ :

1 - without SAA; $2-\mathrm{NaDDS} ; 3-\mathrm{NaDBS}$ 4- katamin $\mathrm{AB} ; 5-\mathrm{NaDBS}+$ katamin $\mathrm{AB}$

A positive effect of surfactants can also be observed at low concentrations $(5 \mathrm{mg} / 1)$ during electroflotation of the $\mathrm{Cr}(\mathrm{OH})_{3}$ deposit in $\mathrm{Na}_{2} \mathrm{SO}_{4}$ solutions. It should be noted that chromium (III) hydroxide is not easily recoverable from sulphate solutions due to the disperse phase particles being too small: the average particle diameter is 13-14 $\mu \mathrm{m}$ at the $\mathrm{pH}$ of $7-8$, the electrokinetic potential in a $1 \mathrm{~g} / 1 \mathrm{Na}_{2} \mathrm{SO}_{4}$ solution is -5 to $-7 \mathrm{mV}$.

Fig. 1 shows how the $\mathrm{Cr}(\mathrm{OH})_{3}$ recovery rate changes in solutions with different $\mathrm{pH}$ values in the presence of surfactants.

Introduction of surfactant leads to a $30-40 \%$ increase in the $\mathrm{Cr}(\mathrm{OH})_{3}$ recovery rate and a wider $\mathrm{pH}$ range associated with higher recovery rates $(\mathrm{pH}=6-9)$. When the anionic surfactant NaDDS and the anionic flocculant M-10 are added, the size of the chromium hydroxide particles increases to 72 and $90 \mu \mathrm{m}$, correspondingly.

The presence of anionic and cationic surfactants at the same time helps expand the $\mathrm{pH}$ range to $10-11$, in which high recovery rates are observed. Introduction of reagents containing $\mathrm{Mg}^{2+}$ and $\mathrm{Ca}^{2+}$ inhibits the electroflotation process in the case of both $\mathrm{Fe}(\mathrm{OH})_{3}$ and $\mathrm{Cr}(\mathrm{OH})_{3}$. The recovery rates can reach $18-20 \%$ (48-50\% with no additives used) (see Table 2 ).

\begin{tabular}{|c|c|c|c|c|c|c|c|c|}
\hline \multicolumn{9}{|c|}{$\begin{array}{l}\text { Table 2. Effect of surfactants of different types on the extraction } \\
\text { of } \mathrm{Cr}(\mathrm{OH})_{3} \text { by electroflotation in the presence of excess calcium } \\
\text { and magnesium ions }\end{array}$} \\
\hline \multirow{3}{*}{$\begin{array}{c}\text { Time } \tau, \\
\min \end{array}$} & \multicolumn{8}{|c|}{ Recovery rate, $\alpha, \%$} \\
\hline & \multicolumn{4}{|c|}{$\mathrm{Mg}^{2+}$} & \multicolumn{4}{|c|}{$\mathrm{Ca}^{2+}$} \\
\hline & w/o SAA & cat. & an. & nonion. & $w / o$ & cat. & an. & nonion. \\
\hline 5 & 11 & 14 & 88 & 10 & 11 & 12 & 96 & 11 \\
\hline 10 & 14 & 18 & 93 & 12 & 14 & 14 & 99 & 13 \\
\hline 20 & 20 & 22 & 95 & 15 & 18 & 20 & 99 & 18 \\
\hline
\end{tabular}

As it is in the case of $\mathrm{Fe}(\mathrm{OH})_{3}$, when anionic surfactant is added, it leads to chromium hydroxide surface hydrophobization and the recovery rate increased to 95-99\%.

Together with Fe, Cr, Al, Zn, Ni, Cu ions, salts (such as chlorides and sulphates) are commonly present in wastewater, and their concentrations can reach 10-100 g/1. In the case of such process solutions, the extraction by electroflotation process can be less efficient [27, 28].

Brines are often the result of process solutions being dumped in wastewaters or of the ion exchange process, in which eluates form that contain ions of $\mathrm{Fe}, \mathrm{Cr}, \mathrm{Al}, \mathrm{Zn}$, $\mathrm{Cu}$ and inorganic salts.

Tables 3 and $\mathbf{4}$ below show the results of experiments that looked at the extraction by electroflotation of $\mathrm{Fe}, \mathrm{Cr}$ and $\mathrm{Al}$ hydroxides from the following process solutions: $10 \mathrm{~g} / 1 \mathrm{NaCl}$ and $10 \mathrm{~g} / 1 \mathrm{Na}_{2} \mathrm{SO}_{4}$ (ion exchange eluates).

Analysis shows that only $\mathrm{Fe}(\mathrm{OH})_{3}$ can be efficiently extracted without using a surfactant. The recovery rate $(\alpha)$ reaches $93 \% ; 20 \%$ for $\mathrm{Al}(\mathrm{OH})_{3} ; 14 \%$ for $\mathrm{Cr}(\mathrm{OH})_{3}$. Introduction of $5 \mathrm{mg} / \mathrm{l}$ of anionic surfactant (NaDBS) results in a drastic rise in the recovery rate for all three metals.

Extraction by electroflotation of hydroxides from sodium sulphate solutions has a lower efficiency. Introduction of NaDDS helps intensify the electroflotation process bringing the recovery rate up to 93-97\%. It should be noted that, when both $\mathrm{Cr}(\mathrm{OH})_{3}$ and $\mathrm{Fe}(\mathrm{OH})_{3}$ are present, the average disperse phase particle size is $45 \mu \mathrm{m}$, and it is $65 \mu \mathrm{m}$ for the $\mathrm{Cr}-\mathrm{Fe}-\mathrm{Al}$ system.

\begin{tabular}{|c|c|c|c|c|c|c|}
\hline \multicolumn{7}{|c|}{$\begin{array}{l}\text { Table 3. Effect of anionic surfactant on the extraction } \\
\text { by electroflotation of } \mathrm{Fe}(\mathrm{OH})_{3}, \mathrm{Al}(\mathrm{OH})_{3}, \mathrm{Cr}(\mathrm{OH})_{3} \text { hydroxides } \\
\text { from the } \mathrm{NaCl} \text { solution }(10 \mathrm{~g} / \mathrm{l})\end{array}$} \\
\hline \multirow{3}{*}{$\underset{\min }{\operatorname{Time} \tau}$} & \multicolumn{6}{|c|}{ Recovery rate, $\alpha, \%$} \\
\hline & \multicolumn{3}{|c|}{ without SAA } & \multicolumn{3}{|c|}{ NaDDS } \\
\hline & $\mathrm{Fe}(\mathrm{OH})_{3}$ & $\mathrm{Al}(\mathrm{OH})_{3}$ & $\mathrm{Cr}(\mathrm{OH})_{3}$ & $\mathrm{Fe}(\mathrm{OH})_{3}$ & $\mathrm{Al}(\mathrm{OH})_{3}$ & $\mathrm{Cr}(\mathrm{OH})_{3}$ \\
\hline 5 & 82 & 10 & 11 & 93 & 82 & 80 \\
\hline 10 & 92 & 15 & 13 & 95 & 84 & 82 \\
\hline 20 & 93 & 20 & 14 & 96 & 96 & 90 \\
\hline
\end{tabular}

Table 4. Effect of anionic surfactant on the extraction by electroflotation of $\mathrm{Fe}(\mathrm{OH})_{3}, \mathrm{Al}(\mathrm{OH})_{3}, \mathrm{Cr}(\mathrm{OH})_{3}$ hydroxides from the $\mathrm{Na}_{2} \mathrm{SO}_{4}$ solution $(10 \mathrm{~g} / \mathrm{l})$

\begin{tabular}{|c|c|c|c|c|c|c|}
\hline \multirow{2}{*}{$\begin{array}{c}\text { Time } \tau \\
\text { min }\end{array}$} & \multicolumn{5}{|c|}{ Recovery rate, $\alpha, \%$} \\
\cline { 2 - 7 } & $\mathrm{3}$ without SAA & \multicolumn{3}{c|}{$\mathrm{NaDDS}$} \\
\hline 5 & 45 & 11 & 16 & 90 & 62 & 44 \\
\hline 10 & 60 & 15 & 18 & 93 & 76 & 52 \\
\hline 20 & 65 & 18 & 20 & 97 & 83 & 60 \\
\hline
\end{tabular}

Conditions: $c\left(\sum \mathrm{Me}^{3+}\right)-300 \mathrm{mg} / \mathrm{l} ; c\left(\mathrm{Na}_{2} \mathrm{SO}_{4}\right)-10 \mathrm{~g} / \mathrm{l}, \mathrm{pH}-7.0$, $J_{\mathrm{v}}-0.4 \mathrm{~A} / \mathrm{l}, c(\mathrm{SAA})-5 \mathrm{mg} / \mathrm{l}\left({ }^{*}-10 \mathrm{mg} / \mathrm{ISAA}\right)$ 


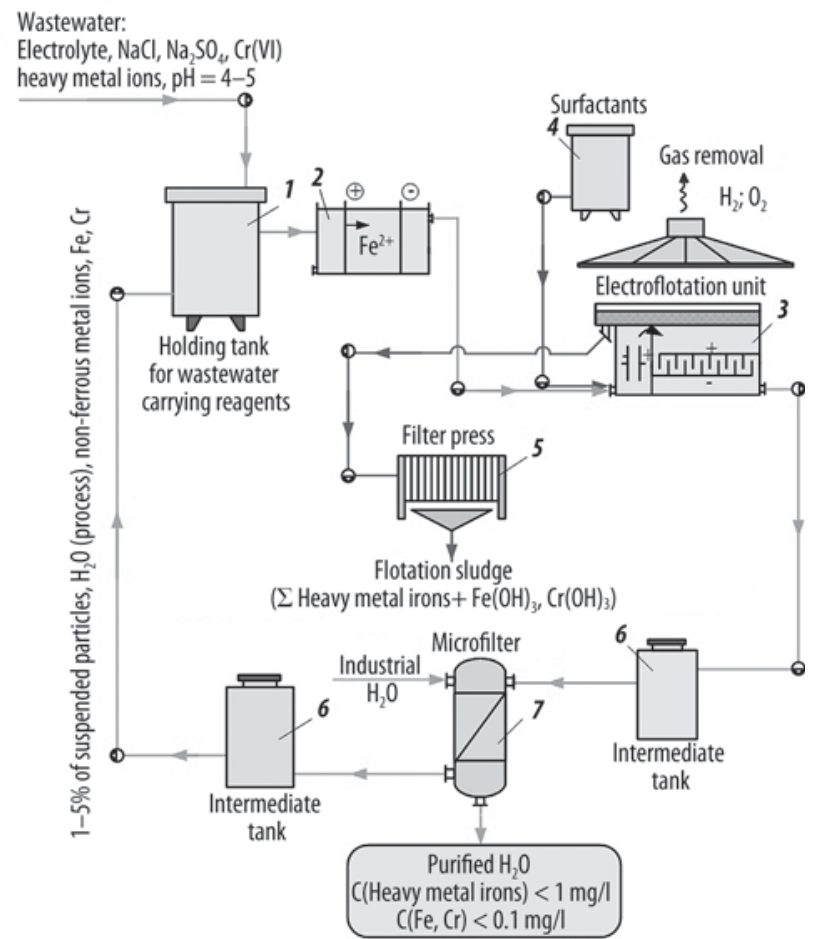

Fig. 2. Principal diagram: Treatment of wastewater carrying heavy metal ions, $\mathrm{Cr}$ (IV) through electrocoagulation and electroflotation: 1- holding tank; 2 - electrocoagulator; 3 - electroflotation unit; 4- container with anionic surfactant; 5 - filter press; 6- intermediate tank; 7- Microfilter

Along with laboratory studies, there is some process work that is carried out to examine the application of electroflotation and coagulation for wastewater treatment using $\mathrm{FeCl}_{3}$ and $\mathrm{AlCl}_{3}, \mathrm{Ti}(\mathrm{OH})_{4}$, flocculants and surfactants [29-31]primarily for poorly extractable systems, such as oil-containing wastewater generated by steel rolling mills [29].

On the basis of the conducted studies and practical experience, the authors propose certain treatment processes applicable to wastewater containing iron and chromium hydroxides, as well as organic contaminants.

Fig. 2 shows a principal diagram of the electrocoagulation and electroflotation processes aimed at removing $\mathrm{Cr}(\mathrm{III}), \mathrm{Cr}(\mathrm{VI})$ and $\mathrm{Fe}$ (III) from wastewater.

Two basic modules are used for treatment of water carrying iron (II, III) ions: an electroflotation unit and a microfilter. The electroflotation unit recovers 95-98\% of the deposit in 10-15 minutes, and $1-5 \%$ of suspended particles are recovered by the filter. The main deposit is formed in the electroflotation unit. The moisture content of the deposit is $96-97 \%$. The amount of the deposit is dictated by the initial concentration of $\mathrm{Fe}^{3+}\left(\mathrm{g} / \mathrm{m}^{3}\right)$ and the capacity of the unit ( $\mathrm{m}^{3} /$ hour). This process works if the concentration of the $\mathrm{NaCl}$ and $\mathrm{Na}_{2} \mathrm{SO}_{4}$ salts is $1-50 \mathrm{~g} / 1$, that of the suspended particles is $<200 \mathrm{mg} / 1$, and that $\mathrm{Fe}^{3+}$ is $<500 \mathrm{mg} / 1$.

The treatment process for wastewater carrying suspended particles and hexavalent chromium (see Fig. 2) involves the processes of electrocoagulation, electroflotation and microfiltering. What differentiates this process from the approach described above is that this process is based on the use of an electrocoagulator with a steel anode (metal, shavings) that serves to reduce $\mathrm{Cr}(\mathrm{VI})$ to $\mathrm{Cr}$ (III). It is possible due to $\mathrm{Fe}(\mathrm{II})$ accumulated in wastewater. Then, an electroflotation unit is used to separate a mixture of $\mathrm{Fe}(\mathrm{OH})_{3}$ and $\mathrm{Cr}(\mathrm{OH})_{3}$. The recovery rate is 95-97\%; the concentration of $\mathrm{NaCl}$ and $\mathrm{Na}_{2} \mathrm{SO}_{4}$ salts is $1-50 \mathrm{~g} / 1$.

To realize the above described techniques, the authors propose to use electroflotation units with the capacities of 1,5 and $10 \mathrm{~m}^{3} / \mathrm{h}$. More information on such units can be found in the following papers: $[15,21]$. These units are characterized with a low power consumption $(0.3-$ $0.5 \mathrm{~kW} \cdot \mathrm{h} / \mathrm{m}^{3}$ treated water), a short separation (extraction) time (not exceeding 10 minutes) and a recovery rate reaching 95-98\%; the throughput is $5 \mathrm{~m}^{3}$ of water per $1 \mathrm{~m}^{3}$ of the unit; the cost of the unit per $10 \mathrm{~m}^{3} / \mathrm{h}$ does not exceed 1.5 million rubles.

\section{Conclusion}

The conducted study shows that it is in the presence of anionic surfactants that the process of extracting hydrophilic $\mathrm{Fe}, \mathrm{Al}, \mathrm{Cr}$ hydroxides by electroflotation reaches its highest efficiency.

Though $\mathrm{Ca}^{2+}$ and $\mathrm{Mg}^{2+}$ ions inhibit the electroflotation process, positive effects are observed when the concentration of surfactant is low: Me:SAA - 100:(5-10). This can be attributed to hydroxide surface adsorption and surface hydrophobization.

The described effects lead to a shorter electroflotation time, a higher recovery rate and lower power costs. $\mathrm{Fe}(\mathrm{OH})_{3}-\mathrm{SAA}$ and $\mathrm{Al}(\mathrm{OH})_{3}-\mathrm{SAA}$ used as flocculants prove to be efficient in extracting the powders of $\mathrm{TiO}_{2}$, 'OU-B', TiC, $\mathrm{SiC}, \mathrm{SiO}_{2}$ by electroflotation with the recovery rate reaching $95 \%$.

This research study was funded by D.Mendeleev University of Chemical Technology of Russia, Project no. 3-2020-004.

\section{REFERENCES}

1. Kolesnikov V. A., Ilyin V. I., Brodskiy V. A., Kolesnikov A. V. Electroflotation in water treatment processes and extraction of valuable components from liquid man-made wastes. Review. Part 1. Teoreticheskie osnovy khimicheskoy tekhnologii. 2017. Vol. 51. No. 4. pp. 361-375. DOI: 10.7868/ S0040357117040054.

2. Filatova E.G. Removal of heavy metal ions from wastewater: Overview of water treatment techniques based on physical and chemical processes. Izvestiya Vuzov. Prikladnaya khimiya $i$ biotekhnologiya. 2015. No. 2 (13). pp. 97-109.

3. Nepochatov V. M., Kolesnikov V. A., Kharlamov V. I., Tokov M. Yu. Developing a process to obtain electrolytic manganese from the low-grade carbonate ores of the Usinsk deposit. Problemy chernoy metallurgii i materialovedeniya. 2012. No. 1. p. 19. 
4. Kors L. G., Kors N. V., Pavelkova Yu. S. Choosing effective inhibitors for phosphorous acid pickling of steel. Izvestiya KGTU. 2011. No. 20. pp. 76-83.

5. Shukhenina Z. M., Bagrov V. V., Desyatov A. V., Zubkov A. A., Kamrukov A. S., Kolesnikov V. A., Konstantinov V. E., Ksenofontov B. S., Novikov D. O. Industrial water. Problems, technology, waste recoverability. Moscow : MGTU im. N. E. Baumana. 2015. $401 \mathrm{p}$.

6. Kovalev V. V., Kovaleva O. V. Theoretical and practical aspects of electrochemical water treatment: Monograph. Kishinev : Poligraficheskiy tsentr Moldavskogo gosudarstvennogo universiteta, 2003. $415 \mathrm{p}$.

7. Butorina I. V. The main directions of improvement of ecological parameters in iron and steel production. Chernye Metally. 2014. No. 4. pp. 21-25.

8. Degel R., Fröhling Ch., Hansmann T., Kappes H., Barozzi $\mathrm{S}$. The concept of waste-free fabrication of metallurgical products. Chernye Metally. 2016. No. 4. pp. 40-49.

9. Kolesnikov A. V., Kharlamova T. A., Silos O. V., Alaferdov A. F., Semenov Yu. V., Zhukov V. Yu. Advanced electrochemical processes for wastewater neutralization. Part III. Electrocoagulation. Galvanotekhnika i obrabotka poverkhnosti. 2015. Vol. XXIII. No. 2. pp. 47-57.

10. Chen G. Electrochemical technologies in wastewater treatment. Separation and Purification Technology. 2004. Vol. 38(1). pp. 11-41.

11. Moussa D. T., El-Naas M. H., Nasser M., Al-Marr M. J. A comprehensive review of electrocoagulation for water treatment: Potentials and challenges. Journal of Environmental Management. 2017. Vol. 186. pp. 24-41.

12. Attour A., Touati M., Tlili M., Ben Amour M., Lapicque F., Lecrecr J. P. Influence of operating parameters on phosphate removal from water by electrocoagulation using aluminum electrodes. Separation and Purification Technology. 2014. Vol. 123. pp. 124-129.

13. Sulimova M. A., Sizyakov V. M., Litvinova T. E., Vasilyev V. V. On possibility of the use of metallurgical production wastes as a sorbent in the industrial water cycle. Chernye Metally. 2016. No. 8. pp. 43-49.

14. Chen X., Chen G. Electroflotation. Electrochemistry for the Environment. 2010. 263 p.

15. Kolesnikov V. A., Menshutina N. V., Desyatov A. V.. Equipment, technology and design of wastewater treatment systems. Moscow : DeLi plyus, 2016. 289 p.

16. Garcia-Segura S. et al. Electrocoagulation and advanced electrocoagulation processes: A general review about the fundamentals, emerging applications and its association with other technologies. Journal of Electroanalytical Chemistry. 2017. Vol. 801. pp. 267-299.

17. Desyatov A. V., Baranov A. E., Baranov E. A., Kakurkin N. P., Kazantseva N. N., Aseev A. V. The practice of using membrane technology for water treatment and desalination. Ed. by A. S. Koroteeva. Moscow : Khimiya. 2008. 240 p.

18. Dmitriev E. A., Kolesnikov V. A., Trushin A. M., Brodskiy V. A., Komlyashev R. B. Some hydromechanical aspects of microflotation. Teoreticheskie osnovy khimicheskoy tekhnologii. 2015. Vol. 49. No. 5. p. 489.
19. Ksenofontov B.S. Wastewater treatment: Flotation kinetics and flotation machines: Monograph. Moscow : ID "FORUM": INFRA-M. 2020. 256 p.

20. Ksentini I., Kotti M., Ben Mansour L. Effect of liquid phase physicochemical characteristics on hydrodynamics of an electroflotation column. Desalination and Water Treatment. 2014. Vol. 52 (16-18). p. 3347.

21. Kolesnikov V. A., Kolesnikov A. V., Ilyin V. I. Electroflotation in wastewater treatment to remove petroleum products, pigments, surfactants, ligands and bacteria. Review. Part 2. Teoreticheskie osnovy khimicheskoy tekhnologii. 2019. Vol. 53. No. 2. pp. 205-228. DOI: 10.1134/S004035711901009319.

22. Sillanpää M., Shestakova M. Electrochemical Water Treatment Methods: Fundamentals, Methods and Full Scale Application. 2017. 310 p.

23. Than So Htay, Maslyannikova D. V., Kheyn T. A., Kolesnikov V. A. Effect of magnesium, calcium and barium ions on the recovery of iron (III) hydroxides by electroflotation. $\mathrm{Wa}$ ter: Chemistry and Ecology. 2019. No. 10-12. pp. 80-85.

24. Kashkovskiy V. I. Comprehensive treatment of leakage waters: Information on filtrate neutralization. Municipal Solid Waste. 2010. No. 4. pp. 34-39.

25. Kolesnikov V. A., Ladygina Yu. Sh., Kolesnikov A. V., Mets E. A., Maslyannikova D. V. Main regularities in the extraction of anionic and cationic surfactants from aqueous solutions by electroflotation and sorption. Izvestiya vysshikh uchebnykh zavedenii, seriya khimiya i khimicheskaya tekhnologiya. 2019. Vol. 62. No. 3. pp. 114-120. DOI: 10.6060/ivkkt.20196203.5789.

26. Kolesnikov A. V., Milyutina A. D., Ladygina Yu. Sh., Kolesnikov V. A. Developing an electroflotation process for extracting anionic surfactants and non-ferrous metal ions from galvanizing industry wastewater. Zhurnal prikladnoy khimii. 2018. Vol. 91. No. 7. pp. 939-948.

27. Brodskiy V. A., Kolesnikov V. A. Efficiency of extracting poorly soluble copper compounds from wastewater by electroflotation and how it is governed by the nature of the disperse phase and the salts contained in the medium. Galvanotekhnika $i o b$ rabotka poverkhnosti. 2013. Vol. 21, Iss. 2. pp. 48-54.

28. Kolesnikov A. V., Achkasov M. G., Kandelaki G. I., Kovalenko V. S., Kolesnikov V. A. Optimized recovery of metal hydroxides as part of multicomponent systems from aqueous media by electroflotation. Zhurnal prikladnoy khimii. 2018. Vol. 91. Issue 6. pp. 793-797.

29. Maksimov E. A., Ostsemin A. A. Use of electroflotation to achieve intensified treatment of emulsion- and oil-containing wastewater generated by rolling mills. Metallurg. 2014. No. 11 . p. 27.

30. Aung Pyaye, Hein Thu Aung, Kolesnikov A. V. Effect of the phosphating chemical Decorrdal on the extraction of poorly soluble compounds of $\mathrm{Cu}, \mathrm{Ni}, \mathrm{Zn}, \mathrm{Co}, \mathrm{Fe}, \mathrm{Al}$ from rinse- and wastewater by electroflotation. Galvanotekhnika i obrabotka poverkhnosti. 2019. Vol. 27. No. 2. pp. 31-39.

31. Kuzin E. N., Krutchinina N. E.. Purification of circulating and waste water in metallurgical industry using complex coagulants. CIS Iron and Steel Review. 2019. Vol. 18. pp. 72-75. 